\begin{tabular}{|c|c|c|}
\hline Article & Issue & Page \\
\hline \multicolumn{3}{|l|}{ PS Reports } \\
\hline The 30th Anniversary Issue of PS & March 1998 & 1 \\
\hline Editorial Policy & March 1998 & 2 \\
\hline PS Index of Authored Articles & March 1998 & 131 \\
\hline Index of APSA Reports in PS & September 1997 & 623 \\
\hline \multicolumn{3}{|l|}{ Publications } \\
\hline Publications List & September 1997 & 675 \\
\hline Publications List & December 1997 & 877 \\
\hline Publications List & March 1998 & 134 \\
\hline Publications List & June 1998 & 304 \\
\hline \multicolumn{3}{|l|}{ Research Support } \\
\hline Association Awards Graduate Student Grants & December 1997 & 777 \\
\hline Travel Grant Programs Assist International Scholars & December 1997 & 777 \\
\hline APSA To Sponsor Research Support Poster Session & June 1998 & 270 \\
\hline Travel Grants for 1998 Annual Meeting & June 1998 & 270 \\
\hline \multicolumn{3}{|l|}{ Women and Minorities } \\
\hline Ralph Bunche Students Present Papers at Annual Meeting & December 1997 & 778 \\
\hline APSA Announces 1998-1999 Minority Fellows & March 1998 & 96 \\
\hline APSA Names 1998 Ralph Bunche Institute Participants & June & 273 \\
\hline Minority ID Project's New Spring Round a Success & September 1997 & 617 \\
\hline Minority Identification Project Joined by Five New Core Schools & March 1998 & 95 \\
\hline
\end{tabular}

Bennett Bertenthal, head of the Directorate of Social, Behavioral, and Economic Sciences, has proposed reorganizing the Directorate to facilitate the speedy and judicious review of research proposals and to encourage interdisciplinary research. One of Caldwell's first decisions will be whether to authorize the reorganization, which would split the Directorate into a Division of Behavioral and Cognitive Sciences and a Division of Social and Economic Sciences. Additionally, Caldwell will be working with a new Political Science Program Officer, Marianne Catherine Stewart, who is an expert on British and Canadian labor politics and a professor of government at the University of Texas at Dallas (see article below).

In recognition of the importance of, and as a sign of its growing commitment to, interdisciplinary research, NSF has unveiled a number of specifically interdisciplinary grants programs. The most important, and best funded, of these is Knowledge and Distributed Intelligence (KDI). Research funded through KDI will focus specifically on the role knowledge plays in the construction, operation, maintenance, and perpetuation of complex systems. Other interdisciplinary NSF programs in- clude Life and Earth's Environment and Educating for the Future.

Full information about the recent changes at NSF, and about all the Foundation's activites, can be found on the NSF web site (www.nsf.gov).

\section{New NSF Political Science Program Director Appointed}

Marianne C. Stewart has been appointed to the position of Political Science Program Director in the Division of Social, Behavioral and Economic Research at NSF. She joins Dr. Frank Scioli on September 1. Stewart was awarded her B.A. Honours and M.A. degrees in political science from the University of Windsor in Canada. After receiving her Ph.D. in political science from Duke University, she served on the faculty of Rutgers University. She currently is professor of government, politics and political economy at the University of Texas at Dallas.

Her research focuses on how economics and politics, and emotions and evaluations, shape party support decisions. She also has been involved in studies of gender effects on the political economy of such decisions, and citizen participation in AngloAmerican and other democracies.
She is coeditor of Economic Decline and Political Change (1989), coauthor of Controversies in Political Economy (1992), and at work on New Labour's New Beginnings: The Political Economy of Party Support in the Post-Thatcher Era with Harold Clarke and Paul Whiteley. Her most recent articles include "The Dynamics of Party Identification in Federal Systems," American Journal of Political Science (1998), "New Models for New Labour," American Political Science Review (1998), and "Tory Trends," British Journal of Political Science (1997) with Clarke and Whiteley.

Stewart participated in the formation of NSF's Democratization Initiative and was a member of the Advisory Panel of NSF's Political Science Program. She also has been assistant editor of the Journal of Politics, a member of the editorial boards of the American Journal of Political Science and Structural Equation Modeling, a chair of the program committee of the 1994 Midwest Political Science meeting, and a member of the executive councils of the Midwest and the Southern Political Science Associations. She is a member of the American, Midwest, Southern, and Canadian Political Science Associations, the British Politics Group, and the Women's Caucus for Political Science. During the past two years, she has been director of graduate studies in the School of Social Sciences at her university.

\section{More on Affirmative Action Bans and Higher Education}

Over the past three years, a series of procedural and legal bans on using race and gender as criteria for admission to institutions of higher education have been put in place in California and Texas. Several other states and school systems are currently considering similar bans. $P S$ has been reporting on the impact these bans have had on minority enrollments and will continue to do so. Some of the more interesting facts 